Journal of Qualitative Criminal Justice \& Criminology

\title{
Exploring Police
}

\section{Legitimacy Perceptions}

\section{Among Arab and Chaldean}

\section{Business Owners in Detroit}

\author{
Vaughn J. Crichlow ${ }^{1}$, Edmund F. McGarrell ${ }^{2}$ \\ ${ }^{1}$ Florida Atlantic University, ${ }^{2}$ Michigan State University
}

Published on: Aug 15, 2020

DOI: 10.21428/88de04a1.dad704df

License: Creative Commons Attribution 4.0 International License(CC-BY 4.0) 


\section{ABSTRACT}

Most agree that police officers cannot do their jobs effectively without the support of community members. However, little is known about the perceptions of small business owners who could potentially make a meaningful contribution to safety and security in such communities. There is also a paucity of research on immigrant-owned businesses in disorderly urban communities. To address the gap, this study explores the attitudes of small business owners toward the police in Detroit, Michigan, a city known for high levels of violent crime and presents an analysis of the qualitative data collected from in-depth interviews with small business owners $(n=39)$, with a special focus on Arab and Chaldean business owners. The findings indicate that although procedural justice perceptions are closely associated with police legitimacy perceptions, business owners are equally concerned about the effectiveness of police in dealing with crime. In particular, the perceived risk of victimization influences many Arab and Chaldean business owners' perceptions of police. The policy implications of these findings are discussed.

\section{Introduction}

It is challenging for police to do their jobs effectively when residents do not trust them (Gau, 2011; Tyler \& Wakslak, 2004). This is particularly the case in disorderly urban communities. Similar to the residents, business owners may view the police unfavorably which can pose an additional challenge for police officers who must investigate crimes in hotspots often comprised of problematic gas stations and convenience stores (Dalmia, 2013; Rice \& Parkin, 2010). Simply put, police legitimacy can be defined as the degree to which individuals trust and have confidence in the police (Tyler, 2002). Police are viewed as legitimate when deemed to possess "the moral and not merely legal authority to issue commands, keep the peace, and enforce the law" (Gau et al., 2012, p. 334).

If meaningful interactions between the police and the community lead to more favorable perceptions of police, these interactions may also encourage stronger community partnerships that foster safer communities. Small business owners can be included in such initiatives, and this could be crucial to the survival of troubled communities (Brodwin, 2012; Dymski, 1996; Greenbaum \& Tita, 2004). It is therefore worthwhile to consider the perspectives of business owners. Furthermore, it is unclear whether factors such as race, type of business, recent encounters with police and experiences with crime, along with the fear and perceived risk of victimization play a role in business owners' attitudes toward police.

Prior research has paid little attention to the attitudes and experiences of business owners, particularly Middle Eastern owners who operate in many of America's most disorderly urban centers. This study makes a contribution by exploring police legitimacy perceptions among small business 
owners in areas known for high levels of violent crime. With a focus on Arab and Chaldean business owners, this research presents the analysis of qualitative data collected from in-depth interviews with Detroit business owners.

\section{The case of Detroit}

Detroit is the most populous city in Michigan with a population of approximately 700,000 in the city and 5 million in the Metro area (U.S. Census, 2010). The city has experienced a population decline of approximately 63\% since it peaked at almost 2 million residents in 1950 (Harris, 2013). At the time of writing, Detroit is the largest American city to ever file for bankruptcy. It has a violent crime rate of almost five times the national average and was also ranked for the fourth straight year as the most dangerous city in the country (Dudar, 2013; Forbes, 2013).

Small business owners and urban residents now face an uncertain future as the Detroit Police Department is saddled with a consent decree due to a range of abuses, as the city tries to overcome the consequences of neglect, financial mismanagement, corruption and gross misconduct in high office. 1 Business closures are increasing due to concerns about crime victimizations and general public safety, less than adequate police response-times to life-threatening emergencies, high business taxes, and the seemingly sudden and aggressive enforcement of business codes and regulations (Dalmia, 2013; Dudar, 2013).

Detroit is of particular interest given the racial and ethnic differences within the business community. Many of the business owners who participated in this study are of Arab or Chaldean origin, or ancestry, and this reflects the largest communities of immigrant business owners in the city. There is limited research on these groups. The Arab and Chaldean communities in particular are responsible for many of the surviving small businesses in the city and in the metro area. While the Arabs in Detroit are generally Muslim and come from a range of Middle Eastern countries, most Chaldeans in Detroit can trace their roots to a northern Iraqi province. Furthermore, unlike their Muslim counterparts who speak Arabic, the native language of the Chaldeans is Aramaic, and they are predominantly Roman Catholic (Spurlock \& Liedka, 2013).

In this study, Middle Eastern loosely refers to people originating from countries in Southwest Asia between Egypt and India. It may be an imperfect term for the people of this region, and it could be viewed as inadequate in describing such a wide range of cultures and ethnicities (Schopmeyer, 2011). Notwithstanding this consideration, Middle Eastern is used in this study as an organizing category for the purpose of analysis. Examining Arab and Chaldean responses within this category is useful in generating comparisons and identifying common experiences among business owners. Furthermore, there are race-related perceptions that stem from interactions with the predominantly African 
American residential population, which comprises the customer base for these businesses, and it is possible that Arabs and Chaldeans share these perceptions.

Existing research on business owners in Detroit has generally used a socio-historical approach in exploring interactions between immigrant owners and their customers (Gold, 2010). This approach was also used in examining the challenges faced by African American business owners and the need for entrepreneurial development in the African American community (Darden \& Thomas, 2013; Gold, 2010). Studies have also used socio-historical and economic models in examining family arrangements in Metro Detroit and the success of Arab and Chaldean-owned businesses (Smith, Tang \& San Miguel, 2012; Spurlock \& Liedka, 2013). However, none of these studies has examined attitudes toward the police, and there is no known research on procedural justice perspectives in urban business communities.

The significance of this research rests on the fact that Detroit, like other urban centers, needs successful small businesses. These businesses will not survive if there is no infrastructure to sustain them, and their demise could be hastened if the threat of violent crime is not properly addressed. The findings from this study could have implications for police practice as well as urban development policy, since urban neighborhoods have experienced the detrimental effects of violent crime and the fear of victimization. Meaningful interactions between police and small business owners, particularly Chaldean and Arab business owners, will be crucial to the survival of business activity, the socioeconomic health of urban neighborhoods, and the hope of effective crime reduction efforts.

\section{Police legitimacy perceptions}

Prior research indicates that procedural justice perceptions are an important key to understanding attitudes toward police. Procedural justice refers to individuals' beliefs about whether the police are treating them with respect and making quality decisions (Gau, 2011; Tyler \& Wakslak, 2004). Although unfavorable personal experiences with police have a detrimental effect on the evaluation of future police encounters (Skogan, 2006), it has been suggested that when police exercise their authority with fairness, there will be a greater impact on levels of deference to the police (Taylor \& Lawton, 2012; Tyler \& Huo, 2002). Furthermore, despite the evidence that the performance of the police has a moderate effect on legitimacy, the effect of procedural justice on legitimacy remains strong even when performance measures are removed (Tyler \& Fagan, 2008).

Similarly, when respondents used ethical judgments in regard to the appropriateness of police actions rather than their perceptions of the outcomes of police procedures, these perceptions of fair and respectful treatment determined levels of legitimacy (Tyler, 1988; Tyler \& Huo, 2002). Existing research on the psychology of legitimacy, a crucial component of process-based models, indicates that individuals are more inclined to comply with the institutions that they trust (Jost \& Major, 2001; Tyler, 
2006a), and more likely to obey the law if law enforcement agencies are viewed as legitimate (Tyler \& Fagan, 2008). These findings are useful since they indicate that individuals do not only evaluate police performance in terms of the outcome only; they also respond to the process that leads to the outcome. In other words, the process matters.

The perceptions of community members are also quite subjective and reflect a highly personalized process. Tyler (2002) addressed the issue of subjectivity in terms of a comparison of subjective and objective measures of legitimacy. Subjective measures of legitimacy are based on the attitudes of community members toward the performance and conduct of police officers, whereas objective legitimacy refers to measures of crime rates and observed levels of community disorder. Existing research on legitimacy generally highlights the subjective measures of legitimacy, and has established that police treatment of community members has a stronger effect on legitimacy than the outcomes of police work and the quality of police performance (Bradford, Jackson \& Stanko, 2009; Sunshine \& Tyler, 2003).

Regardless of whether prior experiences with police produced favorable or unfavorable outcomes, legitimacy increased if citizens felt the police used fair procedures (Tyler \& Fagan, 2008). According to these studies, perceptions of personal experiences with police are highly influential in shaping attitudes regarding future encounters with police. Also, perceptions of legitimacy will increase independent of the effect of individuals' personal outcomes, if individuals experience positive procedural justice in their personal encounters with police (Tyler \& Fagan, 2008). It is unclear whether this rubric also applies to small business owners. Extant research generally focuses on the attitudes of members of residential communities.

Regardless of the population being studied, it could be assumed that procedural justice perceptions are more influential than perceptions that stem from the actual outcome of recent interactions with police. However, the likelihood that business owners' concerns are different from the concerns of local residents is worthy of consideration. Perspectives on the sustainability of small businesses suggest that business owners will be more concerned about police performance because adverse circumstances caused by crime and disorder may affect profitability (Tilley, 1993). It is also possible that the perceived risk and fear of victimization will more greatly impact business owners' perceptions of the police than beliefs about respect and quality of decision-making (Greenbaum \& Tita, 2004).

Furthermore, race and ethnic origin may play a role in differential attitudes toward police. Perceptions of the degree to which policing practices are racially biased, whether racial profiling is practiced, and whether police reform is needed, are largely determined by factors related to respondents' race and ethnicity (Bradford et al., 2009; Cao, 2011; Taylor \& Lawton, 2012; Tyler \& Wakslak, 2004; Weitzer \& Tuch, 2005). Racial differences can also be partially explained by the perceived disparate treatment of racial minority populations in terms of heightened police scrutiny and the discriminatory treatment of 
individuals based on race, ethnicity, or perceived religion (Brunson, 2007; Gau, Corsaro, Stewart \& Brunson, 2012; Nguyen, 2005; Rice \& Parkin, 2010). Although this study does not contain a large enough sample to make robust racial or ethnic comparisons, it is noteworthy that many of the small business owners in Detroit are immigrants from Middle Eastern countries. It was therefore worthwhile to compare participants who can be identified as Middle Eastern to the other participants in the study.

Perceptions regarding victimization must also be considered. At the time of writing, there were no studies on the impact of perceived risk and fear of victimization on attitudes toward the police among business owners. These are important factors to consider given that many urban business owners operate in socially disorganized neighborhoods, and concerns about safety in these areas could have an impact on legitimacy perceptions (Sampson, Raudenbush \& Earls, 1997). It is well established that socially disorganized neighborhoods produce conditions that generate and attract crime and deviance. Operating a business within a social and physical context that comprises all of these issues can influence perceptions of crime and policing (Sampson \& Bartusch, 1998). The city of Detroit provides a compelling case for an assessment of these issues.

\section{Methods}

\section{Research design}

The main goal of this research is to explore the attitudes of small business owners toward police in Detroit, with a focus on Arab and Chaldean owners. Along with procedural justice perceptions, this study explores several factors that are believed to influence business owners' perceptions of police in high-crime areas. These factors include type of business, perceptions of recent encounters with police, the fear of victimization, and the perceived risk of victimization. The study is comprised of an exploratory qualitative design that provides an assessment of findings from in-depth interviews. The data were collected over a six-month period with a sample of 39 business owners. The interviews were 45 minutes to 2 hours in length and loosely structured in order to allow participants to discuss their concerns freely.

The types of businesses included in the study were based on preliminary interviews with business owners as well as conversations with two senior police officers from the Detroit Police Department (DPD). It is also established in prior research that certain types of businesses tend to be associated with problematic public spaces (Brantingham, 1984). Furthermore, research on crime hotspots has examined crime generators, attractors and enablers, and determined that public spaces such as gas stations and liquor stores in troubled communities often attract street crimes and disorderly behaviors (Braga, 2008; Brantingham \& Brantingham, 1995). Based on this understanding, it was important to include gas stations, convenience stores and liquor stores in the study to increase the chances of 
obtaining respondents with experiences in high-risk situations for the purpose of meaningful comparisons.

\section{Recruitment of participants}

Preliminary interviews were conducted with three Chaldean business owners on the East Side - an area known for disorderly neighborhoods and high crime rates. The participants were recruited with the assistance of a senior representative from the Chaldean Chamber of Commerce. These interviews were influential in the development of the research questions as well as the interview instrument. The preliminary interviews also guided sampling considerations regarding the size of businesses that should be included in the sample frame.

Researchers have indicated that within any definition of small there can be a range of factors that make smaller enterprises quite different in comparison to larger ones, and these factors can include location and type of business (Lepoutre \& Heene, 2006). However, businesses with fewer employees in high-crime areas are more likely to experience procedural justice and policing issues because they often involve interaction with community members, and they may also be more vulnerable to street crime (Tilley, 1993). It was therefore decided that businesses with 20 employees or less would be the focus of this research, and this size reflects most small businesses in the city.

Participants were selected using snow ball sampling from six principal residential areas of the citythe North East, the East Side, Midtown, Indian Village, the West Side and the South West regions. Business owners located in the central business district in downtown Detroit were not included in this study because most were much larger in size and located in multi-story buildings. Such locations generally do not possess enough of the street-level interactions with police and community members that are necessary for a meaningful study of police legitimacy and procedural justice perceptions. The Eastern and Western regions were included due to their neighborhoods' shared challenges regarding blight (vacant houses and general deterioration), high levels of street gang activity and violent crime; the term 'region' is used loosely here to describe large areas of the city that include multiple districts).

The snow ball sampling approach utilized a chain of relationships within the business community (See Figure 1). The interviews continued until issues and concerns were recurring across subjects, and saturation had been achieved. Some business owners were initially reluctant to participate in this research; at the outset, many of the Arab and Chaldean business owners were not inclined to talk openly. Despite the challenges with potential participants who cancelled appointments or did not respond to phone calls and messages, it made a difference when the researcher was introduced in person by informants.

Six informants with connections to the business community assisted in identifying potential participants. These included two representatives from non-governmental organizations; a retired city 
official with extensive knowledge on business compliance and inspections; an influential technocrat who led a grant funded crime prevention project in the city; a Chamber of Commerce representative; and a college professor with significant experience in the Metro area.

Figure 1. Snowball sampling chart
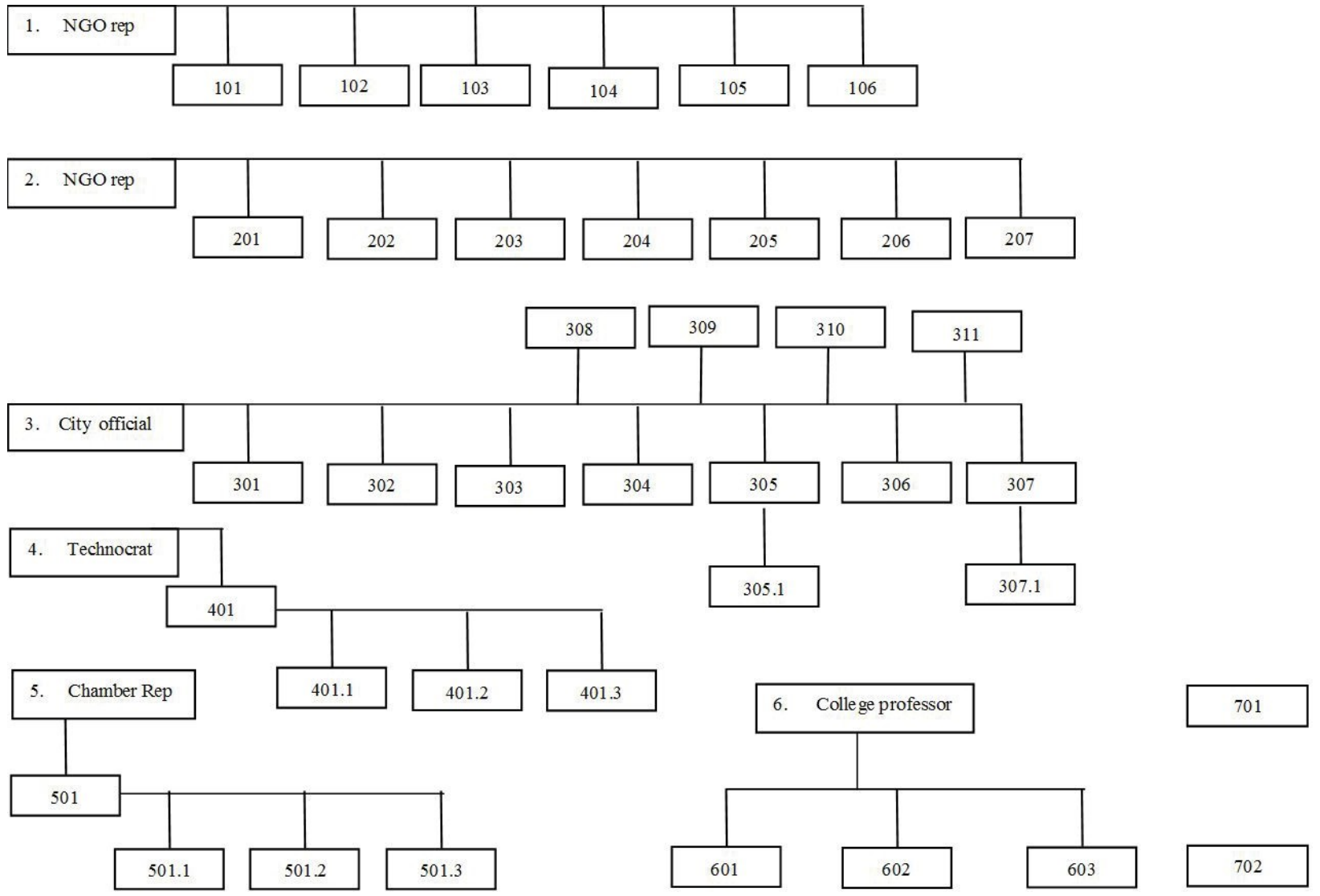

\section{Sample characteristics}

In total, 39 participants were recruited. The majority of them were below the age of 40 (80\%). Regarding race and ethnicity, 19 participants were of Middle-Eastern origin (48\%) and 16 were immigrants. Eight had operated a business in Detroit for less than 5 years, 17 had between 5 and 10 years of experience, and 14 had more than ten years of experience. Only 3 of the participants operated more than one business, and most businesses comprised less than 20 employees (95\%). There were 6 female business owners in the sample. For the North East region there were 9 business owners, 14 from the East Side, 8 from Midtown and Indian Village areas, and 7 from the West Side. There were seven gas station owners, four grocery store owners, four barbers, three owners of fast food franchises and two liquor store owners. Other types of businesses represented were a bar, an auto 
repairs shop, a small construction company, a small financial consultancy firm, a transportation service, a funeral home, electrical services and cleaning services.

The age range of the participants was 24 to 65 with a large percentage between the ages of 30 and 40 (see Table 1). Almost half of the participants were Middle Eastern with white and black participants accounting for $24 \%$ of the sample. Most of the participants had less than 20 years of experience operating businesses in Detroit (86\%) and $11 \%$ possessed more than 30 years of experience. Only 3 participants indicated that they owned or operated more than one business in the city.

A noticeable majority of the participants had less than ten employees (87\%), with $13 \%$ indicating that they had between 10 and 20 employees. Regarding countries of origin, there were four Middle Eastern countries represented (see Table 2). Approximately half of all respondents indicated that they were born in the United States. Iraq had the second largest number of respondents with 15 percent of the sample. Furthermore Table 2 presents the range of business types represented along with the location of the businesses by region, number of employees, and business owners' ethnicity and country of origin.

For the North East region there were 9 business owners, 14 from the East Side, 8 from Midtown and Indian Village areas, and 7 from the West Side (Midtown and Indian Village are less violent areas of the city). The sample was comprised of seven gas station owners, four grocery store owners, four barbers, three owners of fast food franchises and two liquor store owners. Other types of businesses represented were a bar, an auto repairs shop, a small construction company, a small financial consultancy firm, a transportation service, a funeral home, and businesses offering electrical and cleaning services.

Table 1. Description of participants

\begin{tabular}{|l|l|l|}
\hline Characteristics & $\mathrm{n}=39$ & $\%$ \\
\hline Age & & \\
\hline Less than 30 & 8 & $21 \%$ \\
\hline $30-40$ & 23 & $59 \%$ \\
\hline $41-50$ & 4 & $10 \%$ \\
\hline Above 50 & 4 & $10 \%$ \\
\hline
\end{tabular}




\begin{tabular}{|c|c|c|}
\hline \multicolumn{3}{|l|}{ Race } \\
\hline White & 8 & $21 \%$ \\
\hline Black & 12 & $30 \%$ \\
\hline Latino & 0 & 0 \\
\hline Middle Eastern & 19 & $49 \%$ \\
\hline \multicolumn{3}{|l|}{ Immigrant } \\
\hline Yes & 13 & $33 \%$ \\
\hline No & 26 & $67 \%$ \\
\hline \multicolumn{3}{|l|}{ Years in business } \\
\hline Less than 5 & 8 & $21 \%$ \\
\hline $5-10$ & 17 & $44 \%$ \\
\hline $11-20$ & 8 & $21 \%$ \\
\hline $21-30$ & 5 & $14 \%$ \\
\hline More than 30 & 0 & 0 \\
\hline \multicolumn{3}{|c|}{ More than one business? } \\
\hline Yes & 3 & $8 \%$ \\
\hline No & 36 & $92 \%$ \\
\hline \multicolumn{3}{|c|}{ Number of employees: } \\
\hline Less than 10 & 34 & $87 \%$ \\
\hline $10-20$ & 5 & $13 \%$ \\
\hline
\end{tabular}

Table 2. Descriptions of type of business, city region, country of origin and race $(n=39)$ 


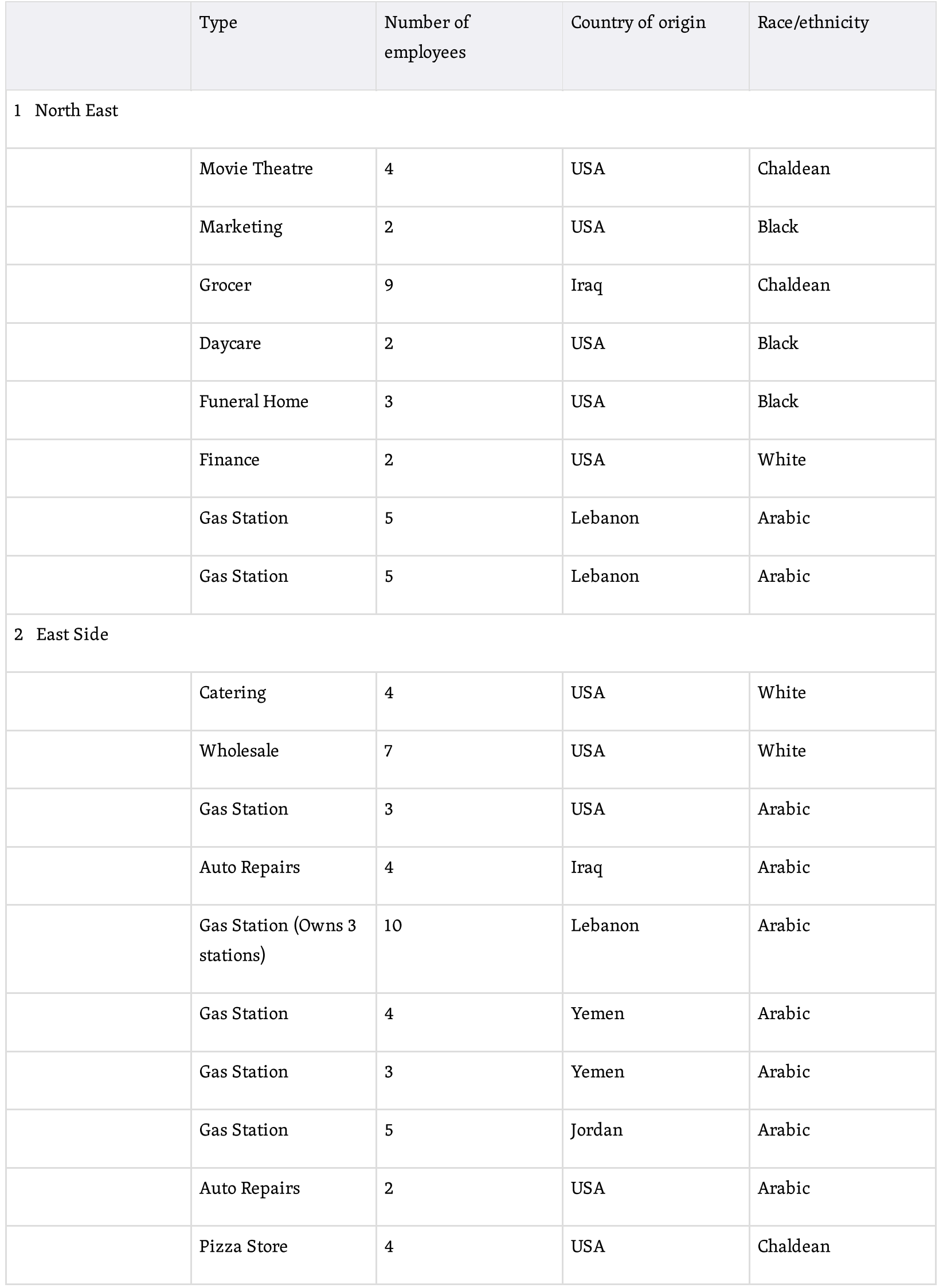




\begin{tabular}{|c|c|c|c|c|}
\hline & $\begin{array}{l}\text { Liquor Store, Mini } \\
\text { Mart \& Cell Phone } \\
\text { Store }\end{array}$ & 13 & Lebanon & Arabic \\
\hline & Electrical Services & 3 & Lebanon & Arabic \\
\hline & Barber & 4 & USA & Black \\
\hline & Barber & 3 & USA & Black \\
\hline & Fast Food & 4 & USA & Black \\
\hline & Fast Food & 3 & USA & Black \\
\hline \multicolumn{5}{|c|}{3 Midtown \& Indian Village } \\
\hline & Bakery & 5 & USA & White \\
\hline & Grocery & 9 & USA & Chaldean \\
\hline & $\begin{array}{l}\text { Groceries (Owns } 2 \\
\text { stores) }\end{array}$ & 11 & Iraq & Chaldean \\
\hline & Barber & 6 & USA & Black \\
\hline & Grocery & 8 & Iraq & Chaldean \\
\hline & Transportation & 3 & USA & Black \\
\hline & Landscaping & 5 & USA & White \\
\hline & Bar & 2 & USA & White \\
\hline \multicolumn{5}{|c|}{4 West Side \& South West } \\
\hline & Construction & 14 & USA & White \\
\hline & Cleaning Services & 4 & USA & Black \\
\hline & Finance & 3 & USA & Black \\
\hline & Barber & 3 & USA & Black \\
\hline
\end{tabular}




\begin{tabular}{|l|l|l|l|l|}
\hline & Liquor Store & 2 & Iraq & Chaldean \\
\hline & Grocery & 11 & Iraq & Chaldean \\
\hline & Gas Station & 3 & Lebanon & Arabic \\
\hline
\end{tabular}

\section{Analysis}

The interviews consisted of open ended questions based on perceptions of the police. The questions were posed in a loosely structured manner which allowed participants to speak freely on related issues. The coding and analysis was guided by Silverman (2010) as well as Miles \& Huberman (1994) regarding the use of keywords and how to efficiently organize data. These data were also coded for relevant themes and categories such as confidence in police performance, prior victimizations and the fear of victimization.

After the first stage of coding was completed a coding protocol was created. Data from the transcripts were then grouped according to theme and relevant labels were created under each conceptual heading. In order to establish reliability an alternative coder with experience in qualitative research was asked to code a sample of eight cases using this coding tool. It is generally accepted that an agreement coefficient of .8 (80\%) indicates acceptable reliability (Gwet 2012; Miles \& Huberman, 1994). Inter-rater reliability was assessed and a Cohen's Kappa statistic of .86 was generated based on the coding of two separate coders.

\section{Findings}

The main themes related to police legitimacy perceptions were respect, trust, police encounters/interactions, police responsiveness, type and location of business, risk, fear and crimes affecting business. The findings indicate that procedural justice perceptions were influential among business owners who appeared to operate under a perceived ongoing threat of victimization and were located in the more disorderly and disadvantaged areas of the city. Participants, however, were equally concerned about the performance of the police and their responsiveness to calls for service. The findings also highlight the perspectives of gas station owners who possessed common concerns that set them apart from the owners of other types of businesses.

\section{Procedural justice and police legitimacy perceptions}

Prior research has measured police legitimacy perceptions in different ways, however, the degree to which participants respect the police and trust the police are key considerations that are generally part of the conceptualization of police legitimacy. Regarding participants' respect for the police, business owners who respect the police were generally mindful of the challenging nature of policing in Detroit and the constraints that impact police work. However, participants who did not respect the police 
believed that police do not care enough about small business owners, particularly those who operate businesses in the most disorderly areas of the city. Most participants also highlighted the physical and social deterioration of the neighborhoods where their businesses were located. For these participants, respect for police is related to perceptions of the responsiveness of police and the performance of police in the communities where their businesses are located.

Regarding the issue of trust, participants who claimed to trust the police believed that most police officers care about the city, and that the violations and abuses perpetrated by a few police officers spoiled the image of the entire department. In contrast, business owners who expressed a lack of trust in the police believed that police officers do not take their jobs seriously and are not concerned about reducing crime or serving citizens. Most participants did not want to condemn the police outright. However, they believed the performance of police officers could be addressed with good leadership and the proper use of city resources. In the following excerpt, Najiv, $\underline{\underline{2}}$ a Chaldean business owner, expressed this point. He acknowledged that police performance needs improvement, but expected things to get better under the new Police Chief:

You know, I haven't had any serious issues with cops. There have been a couple issues and they've kind of got on my case about it. [When] I hit the panic button, 3 or 4 of them showed up pretty quick. That was good. But they told me that [I] can't really use the panic button unless [I'm] getting held up. If I call 911 and we say there's teens fighting in here ... You know there's probably other priorities out there ... Sometimes murders and other stuff. So I can understand it. But am I generally pleased with the performance [of police]? I think it can get better. I think the police chief has plans to make it better.

It was also frustrating to some participants that the necessary changes in police responsiveness were not being implemented by the DPD. The following excerpt is from Nasir, a Lebanese gas station owner on the city's East Side. He expressed frustration regarding the harsh approach taken by police against the selling of loose (single) cigarettes, also known as loosies:

They're saying that in selling loose cigarettes you're attracting certain types of crime, and certain types of people. Me personally, I stopped doing that a long time ago. But with the current DPD authority now getting on national TV, telling about "We're coming after loose cigarettes," we're coming after this, we're coming after that ... This is what I have to say to them. I respect that, that's the law, that's not to be broken I understand. But that's bull crap.

When asked whether they trusted the police, Nasir and others frequently referred to the performance of the police. This suggests that trust and respect for police may be closely associated with perceptions of police performance. For example, participants from the most violent and disorderly areas such as the Osborn neighborhood in the North East, and the Conner area on the East Side, rated police 
performance unfavorably and also had difficulty trusting the police. A Lebanese gas station owner in the South West named Ahmed believed that because the police were underpaid, that this was undermining their ability to be effective. He also believed that many police officers still cared about the city:

This is out of their control I think. Now whether they care ... Yes, they do care. But I really think that they would care more if they make more money. It's just as simple as that. When you tell somebody I want you to do all of this but I'm going to cut your pay by 20 percent. Screw you. I'm not going to do it. Any employee would do that. If I go tell my employees now I'm giving you a 20 percent pay cut starting tomorrow, you think they're gonna be happy? No, they're not gonna work, they're not gonna come in to work.

Long-standing perceptions about policing also appear to impact individuals' perceptions of the police. Participants with favorable perceptions of police often indicated that they grew up with an understanding that police should be respected. Similarly, many participants who possessed unfavorable perceptions could trace these perceptions to negative experiences with police in the distant past. Respect for police as participants grew up was not unique to any one race or culture. USborn business owners also possessed the same value of respect for authority. However, what emerged was that the negative experiences with police during childhood could be quite difficult to overcome, regardless of ethnicity or nationality. The following excerpt is from an interview with Marcus, an African American barber:

I think people feel like the police are almost picking on them. Instead of being around when we actually needed them. They're only around to satisfy something that will benefit them, like if they needed to find a shooter or they needed to bust one more crime. So that's when they hung around the neighborhood, to do something that benefits the police department or make the police department look good. And so it almost was the perception I had growing up ... That the police were out for themselves and not necessarily out for our community.

This perspective was shared by most participants, regardless of race. Concerning recent encounters with police, all of the participants had interacted with police officers within the last 12 months. Participants who operate businesses in high crime areas had frequent encounters with police. When asked about their general perceptions of encounters with the police, some participants indicated that they had friends that were police officers $(40 \%)$ but had a neutral view regarding police performance. Moreover, most indicated that they were not totally satisfied with their most recent encounters with police.

Regarding procedural justice perceptions, the belief that the police were not reciprocating respect was also highlighted. The theme of respect is a key component in the conceptualization of procedural 
justice; if individuals believe that police do not treat them with respect, they will be less inclined to trust the police and see them as legitimate. Seventeen of the 39 participants (44\%) indicated that the police did not treat them with respect, and most of these participants were Arab or Chaldean. This is depicted in the following response given by Mohammed, another gas station owner on the East Side:

My parking lot is private property, and I had a situation where a traffic cop pulled over a customer. And the customer pulled into the parking lot and he came in after him, and he was blocking [the] number one pump. And the way my pumps are set up, it's either one way in or one way out. I had four people being held up by this [police] car pulling over this [other] car. So [I asked the police officer,] "Could you please nicely back up your car so these people can leave, that's all I'm asking." He said "When I'm done I'll do it." How do you deal with a policing authority that shows you no respect?

Due to the frequency of such statements, it was clear that being treated with respect mattered a great deal to business owners. Those who believed they were not being treated with respect were clearly disillusioned by the performance of police and not confident that police were seeking their best interest. Those who were satisfied with their encounters with police indicated that they were treated with respect, and that they understood the reasons for police decision-making. For example, Reggie, a barber shop owner stated, "Well I think they're doing the best job that they can with what they have to work with. Over the years I've fostered a lot of good relationships with police. I'm treated with respect." Perceptions regarding the issue of respect were often linked to police responsiveness. Jamil, a gas station operator from Yemen on the East Side, discussed the issue of respect and police responsiveness in the following excerpt:

I used to have a relationship with the police during the night shift. One gave me his cell number. But I stopped trying [to have a relationship] because they change so often. Some cops work with us, some don't. Some say [only] if they got a gun call us.

Some police officers did not want to be called for service unless there was an incident in which the perpetrator clearly had a gun. This could reflect the DPD's limited resources and the precinct commander's intention to prioritize fatal and non-fatal shootings, which were deemed to be the most serious crimes. Four participants were vocal about this issue and found it to be a very insensitive and unrealistic policy. The general sentiment was that if police believed business owners should only call them when a gun was seen, this could lead to tragic situations that could otherwise be prevented. Furthermore, there were gun crimes that could be prevented if police responded to the threat of violence promptly. Business owners were generally skeptical of the crime prevention capabilities of the police, and this unofficial policy did not have a positive impact on their perceptions. One Chaldean liquor store owner on the West Side, in response to this policy, stated "If I had the money I would invest in the police. They need help." 
Perceptions of encounters with police were closely associated with perceptions of the responsiveness of police to calls for service. An emerging theme in participants' responses to questions about police performance was police response-time to calls for service. Although perceptions of police responsiveness do not directly apply to interactions with police, it was included as part of the conceptualization of procedural justice. The police failure to respond to calls for service, may be interpreted by business owners as disrespect, which is an important component of procedural justice. Police responsiveness is also a clear indicator of perceived performance, and this will have an impact on legitimacy perceptions. Twenty-six participants (67\%) across a range of businesses and ethnicities indicated that they were not satisfied with police response times. Some participants had a great deal to say regarding how response-times affected their confidence in the DPD. Many participants also described crimes and disorderly behavior at or near their businesses and the apparent futility of calling the police.

Although 30 participants were not satisfied with police response-times, what was even more striking was that all of the Middle Eastern respondents, particularly the gas station and liquor store owners had serious concerns about reporting crimes to the police. Ahmad, an Iraqi gas station operator on the West Side stated:

If I catch [members of the community] selling drugs in the area and I tell them to stop, they respond by saying, "I'll blow up that bitch." If I call at four in the morning, maybe they [the police] will come at nine in the night. The only time they come right away is if you say "Please help me, there is a man pointing a gun at me." Police don't do their job right. They don't give a f___ [expletive].

Some participants were generally satisfied with the treatment they receive from police officers during regular encounters or in instances where the police actually responded to a call. However, due to the many instances where police officers were not responsive and did not show up on time, the few instances in which police officers may have been courteous or helpful could not mitigate the overall feelings of frustration regarding their non-responsiveness to calls for service. Participants also indicated that businesses located in the lower crime areas such as Midtown and Indian Village were better served by police when it comes to police patrol and calls for service. Participants in these areas had better relationships with police officers than their counterparts on the East Side.

\section{Risk, fear and victimization}

Certain types of businesses were associated with a higher frequency of victimizations and negative experiences with customers. The risk and fear of victimization and crimes affecting business highlight the importance of exploring comparisons between certain types of businesses. Participants operating businesses that attract disorderly customers and experience a high frequency of interactions with 
customers on the street level generally had less favorable views of police officers. These participants also expressed greater concern about the safety of their family members. In the following excerpt Sandra, an African American owner of a transportation business, discussed a violent incident that affected one of her drivers as well as her customers:

They came out of the bar and they were shooting. They were shooting at our passengers. You know in an altercation like that you tend to run for your vehicle, run to the vehicle that brought you. We had this large amount of people running towards the bus. The passengers were shot and our driver rushed them all to the hospital and this was like a kind of ambulance.

A comparison of note in this study is the contrast between gas station owners' perspectives and those of the participants who operate other types of businesses. The following is another excerpt from Mohammed, the gas station owner, that captures the perceived threat of victimization:

It was 4 oclock in the afternoon. It was a busy Friday, a lady runs into the store while I have five customers in line. "Close the door, close the door. There's two guys following me with a gun." So I hit the automatic switch, I lock her in, I lock all of my customers in, my customers are panicking. "Oh, don't let him in they're gonna come in here and shoot us" [said one customer]. So I did the right thing, I locked the door. I'm not gonna let these folks in. They stood by the door for 15 minutes. After the minute I called in, "Excuse me 911 there's an emergency, two guys outside my door with a weapon. A customer claims they're trying to kill her. I have about six people inside the store and we need your response immediately." They stood out there with guns in broad daylight for fifteen minutes and no DPD unit responded. So as a business owner how does that make me feel about Detroit police. I mean honestly they're over here, currently they're probably doing their job now, but the media is hyping it up a little bit. But that situation right there, we're talking about a person's life plus six people inside a store, plus my life. And these two guys are in a major city with guns in front of a business and the Detroit police cannot respond. So they finally got bored and left. Six hours later Detroit police responded. Oh, "We heard somebody had a gun." This is what I told them, it was like being sarcastic. I'm like, "She's dead and we buried her yesterday."

In another experience with the threat of violence, Mahmoud, a Yemeni gas station operator, stated that he was in a fight for his life with an apparently drunk man who was "out of control and pulling down all the shelves in the store." He expressed frustration that the police did not arrive on the scene until the perpetrator had already gone. Such shocking experiences were not isolated or extreme cases. Similar events were described by participants across the sample who appeared to have regular interactions with customers in the most disorderly neighborhoods. Although there is research that indicates that the level of security implemented by business owners can impact the frequency of victimizations (Linz et al., 2004), the use of security measures was outside the scope of this study. 
Regarding crimes affecting business, 37 participants (95\%) indicated that there was a crime problem in the area where their business is located. Twenty-six participants (67\%) reported that they had been robbed recently, and most of these crimes had occurred at their places of business. It is noteworthy that only 8 participants indicated that they live in Detroit, and some were willing to commute a long distance from home to come to their stores. All of the Chaldean and Arab participants lived in the suburbs. This in itself reflects the general feeling about the greater perceived risk of victimization in the city.

There were 24 participants $(62 \%)$ who reported that they were concerned or afraid that they would be a victim of crime in the future. Although some of the participants had experienced violent crimes while operating their businesses, the majority had experienced theft and other property crimes. The Middle Eastern respondents expressed greater concerns about the risk and fear of victimization. Furthermore, the gas station owners (all Arab) were regularly dealing with shoplifting, vandalism and threats of violence from customers. Disorderly and disrespectful customers appeared to be an even larger issue than crime per se for Middle Eastern participants. Fazil indicated that he was fearful for his life during an incident involving an argument with a customer over the price of gas. In retrospect, he did not think it was worth risking his life over the price of gas, and that was the day he decided that he would eventually look for a way out. He no longer wanted to operate a business in Detroit. He had to think seriously about the well-being of his family, and who would take care of them if he was murdered while at the store. In the following excerpt he discusses these issues:

I have kids at home. I can't risk my life for a quarter and a dollar. I'm willing to trade everything if it came down to the point where my life was at risk and someone had a gun pointed at my head. I would tell him go ahead take the whole store and leave me for my kids ... Because that is the objective as you grow older, you know ... you don't care about yourself, you care about the future of your kids. [To the police chief] come down to the city, come down. Talk to these gas station owners. They'll tell you about the crime; they'll tell you about these dope houses. I grew up in Hamtramck. I've never seen crack cocaine, I've never seen blow, I've never seen a heroin needle, I've never seen these pills until I got here. I've seen everything now.

The gas station owners who happened to all be Middle Eastern immigrants reported a higher frequency of victimizations than other types of business owners. They also reported a greater risk of victimization and were more fearful about the safety of their family members. There was a noticeable difference in their willingness to call the police, due to the fear of retaliation from criminal elements in the community. Furthermore, gas station owners' interactions with disorderly customers were clearly much more volatile than was the case for other types of businesses in the study. 


\section{The salience of race and type of business}

Table 3 presents a number of important comparisons across race/ethnicity, type of business and location. It should also be noted that early in the interview process it became clear that, when it comes to issues of fairness, respect (procedural justice perceptions) and confidence in police performance, Middle Eastern business owners were no different from their US-born counterparts. Their standards of fairness and expectations of the police were no different, and although they were less inclined to be sympathetic toward police, they understood the serious challenges of community safety in the city. They felt there was no excuse for police not to be prepared for these challenges.

Regarding police legitimacy perceptions, gas station owners (and liquor store owners to some degree), viewed police less favorably than all of the other types of businesses included in the study. Gas station owners frequently believed the police were not treating them with respect or making quality decisions and therefore had more unfavorable procedural justice perceptions. Furthermore, gas station owners most often possessed a cynical view of the law and public agencies and were deeply concerned about apparently unfair business compliance requirements.

Table 3. Summary of qualitative findings on key concepts

\begin{tabular}{|c|c|c|}
\hline Key concepts & Race/ethnic differences & Type of business and location \\
\hline Police legitimacy perceptions & $\begin{array}{l}\text { - Arab and Chaldean business } \\
\text { owners viewed police less } \\
\text { favorably than their counterparts } \\
\text { of other racial/ethnic groups. } \\
\text { - The Arab business owners were } \\
\text { less trusting and less confident in } \\
\text { police performance. } \\
\text { Black business owners were the } \\
\text { most sympathetic about the } \\
\text { challenges facing police in Detroit. }\end{array}$ & $\begin{array}{l}\text { - Gas station owners and liquor store } \\
\text { owners viewed police less } \\
\text { favorably than all other types of } \\
\text { business owners included in the } \\
\text { study. } \\
\text { - Attitudes may also be influenced } \\
\text { by location. Business owners in the } \\
\text { more violent and disorderly areas, } \\
\text { such as the North East and the East } \\
\text { Side, viewed police less favorably } \\
\text { than their counterparts in the less } \\
\text { disorderly and comparatively safe } \\
\text { areas, such as Midtown and Indian } \\
\text { Village. }\end{array}$ \\
\hline Procedural justice perceptions & $\begin{array}{l}\text { - Overall there were mixed views } \\
\text { regarding procedural justice } \\
\text { perceptions. } \\
\text { - However, Arab business owners } \\
\text { more frequently believed police }\end{array}$ & \\
\hline
\end{tabular}




\begin{tabular}{|c|c|c|}
\hline $\begin{array}{l}\text { were not treating them with } \\
\text { respect or making quality } \\
\text { decisions. }\end{array}$ & $\begin{array}{l}\text { - Gas station owners often believed } \\
\text { the police were not treating them } \\
\text { with respect or making quality } \\
\text { decisions. Business owners in the } \\
\text { more violent and disorderly areas } \\
\text { complained more frequently about } \\
\text { uncaring or disrespectful police } \\
\text { officers than their counterparts in } \\
\text { other areas. }\end{array}$ & \\
\hline Victimizations & $\begin{array}{l}\text { Arab business owners reported } \\
\text { more victimizations and } \\
\text { experienced a greater perceived } \\
\text { risk of victimization than their } \\
\text { counterparts of other ethnic } \\
\text { groups. } \\
\text { This may be due to the fact that the } \\
\text { Arabs in the sample operated } \\
\text { higher-risk businesses. }\end{array}$ & $\begin{array}{l}\text { - Gas station owners reported a } \\
\text { higher frequency of victimizations } \\
\text { than other types of owners. } \\
\text { - They also reported a greater risk } \\
\text { of victimization and were more } \\
\text { concerned about the safety of } \\
\text { family members. } \\
\text { - Business owners in the more } \\
\text { violent and disorderly locations } \\
\text { were more concerned about the } \\
\text { risk of victimization and were } \\
\text { more fearful of victimization than } \\
\text { those in less violent and disorderly } \\
\text { locations. }\end{array}$ \\
\hline
\end{tabular}

Participants were concerned about violent crime, illegal drugs and property crimes in the areas where their businesses were located. Their views were mixed regarding the police, but most agreed that the performance of police officers and their response time to calls for service needed to be addressed. The immigrant business owners in particular were concerned about disrespectful and unruly customers. Location and type of business mattered. Gas station owners throughout the city seemed to share common issues pertaining to crime, policing, interaction with customers and general issues facing the city.

Attitudes toward the police were complex; most participants had respect for the institution of policing but very few had confidence in police performance, and most did not perceive police to be protecting the interests of the business community. Only five business owners (Four Arab and one Chaldean) indicated that police neglect and poor treatment had anything to do with discrimination. However, all of the immigrant business owners believed that police officers did not care about the plight of small businesses. Furthermore, the Arab business owners believed that Detroit police as well as city officials 
did not care about Arab business owners. Perceptions of procedural justice as well as police legitimacy were very low among this group of participants.

Participants in the Midtown area and in relatively safe neighborhoods such as Indian Village, had more favorable perspectives about their personal dealings with the police. In contrast, participants in areas with more vacant buildings and other signs of disorder possessed more unfavorable views toward police and city officials. These participants also reported more experiences with unruly customers. The Arab business owners were the most frustrated and expressed the most unfavorable perceptions of police. The Chaldeans also expressed unfavorable views with Blacks and Whites, but their opinions were not as pronounced as those of their Middle Eastern counterparts.

There was a noticeable difference between Arab business owners and almost everyone else, and it must be considered whether Arab/immigrant businesses owners were less confident and less trusting in the police due to cultural reasons, or whether this had more to do with the type of business and location. Although cultural differences were beyond the scope of this study, one can make a strong argument for the role of type of business and location based on these findings.

The overall responses suggest that high-pressure situations create greater perceived risk of victimization and are likely to shape perceptions of police. The fact that gas stations are mandated to be open 24 hours a day and are perceived as a natural location for loitering and drug dealing are factors that could contribute to the heightened safety and security concerns that participants experienced. Liquor store owners are also impacted by these factors. Arab owners continually referred to issues of trust, respect and confidence. Most of them did not trust police and did not respect police officers (although they respected the institution of policing). Most did not have confidence in police performance, and there were frequent complaints about the response-time of police officers. Some also believed the police were understaffed and underpaid, and therefore were lacking the necessary motivation to be effective on the job.

\section{Discussion}

The findings from interviews with members of Detroit's small business community provide some support for the assumption that procedural justice perceptions are closely associated with police legitimacy perceptions. The conclusions drawn by Cao (2011), Tyler (2002) and others, that the relationship between procedural justice and legitimacy perceptions are consistent regardless of race, class and community context are partially supported here. When business owners perceived that police were treating them with respect and making quality decisions, they were more inclined to trust and respect the police. This reflects the findings in prior research; individuals are more inclined to comply with the institutions that they trust (Jost \& Major, 2001; Tyler, 2006b; Tyler \& Fagan, 2008). 
Researchers have suggested that police treatment of community members has a stronger effect on legitimacy than the actual outcomes of police work and the quality of police performance (Bradford et al., 2009; Sunshine \& Tyler, 2003). However, this was not supported in the findings from this study. Perceptions about the effectiveness of police in dealing with crime mattered just as much as the way participants were treated by police; business owners may want police to treat them with respect and make quality decisions, but they also want them to be effective in reducing crime. This was particularly the case among the Arab and Chaldean participants who are battling to sustain vulnerable businesses in some of the most violent and disorderly areas.

It is difficult to consider location and type of business separately. It appears that a combination of these factors impacts the seriousness of the crime-related challenges that business owners face on a daily basis. Arab gas station owners in particular seem to experience a combination of issues pertaining to crime, policing, interaction with customers and general issues facing the city. The gas station owners in the eastern parts of the city expressed a great deal of displeasure regarding their experiences with the selling of drugs around their businesses, disorderly customers, dilapidated and desolate surroundings and a shrinking customer base due to declining residential communities. While gas station owners were concerned about the risk of being victims of violent crime, they were also concerned about their interactions with abrasive and unruly customers.

Most business owners had serious concerns about the risk of being victimized. The participants who had regular interactions with the public were much more concerned about the threat of violence. Although procedural justice perceptions appeared to be linked closely to legitimacy perceptions, there was some evidence to suggest that the degree to which business owners feel unsafe would influence their perceptions of interactions with police and their attitudes toward policing and police performance.

\section{Limitations and directions for future research}

The racial distribution of business owners across different types of businesses may be a limitation. Since Middle Easterners own so many of the gas stations and liquor stores in Detroit, which could be deemed as high-risk businesses, it is therefore difficult to draw conclusive findings about race when comparing gas station owners or liquor store owners to the owners of other types of businesses. Such comparisons could lead to more valid results as to whether Arab business owners process procedural justice and legitimacy perceptions differently from their counterparts. However, due to the racial arrangements of business types in the city, this may always be a challenge for researchers to overcome.

There is also a possible limitation in the conceptualization of procedural justice. It is challenging to separate the quality of police treatment from the quality of police performance. For instance, participants who were frustrated about police response times were also not satisfied with the way 
they were treated by the police. For many of them, the non-responsiveness of police was an indicator of mistreatment or disrespect as opposed to a performance measure. This raises the question of whether perceptions of police effectiveness in reducing crime should be incorporated as a separate measure. Future research using quantitative methods can benefit from the use of confirmatory factor analysis to explore the suitability of procedural justice measures. For instance, Gau (2014) sought to address some of the inconsistencies in the measurement of procedural justice and police legitimacy, and also confirms that there is a need for more research along these lines that could also help to define a clear distinction between procedural justice and police legitimacy. More extensive qualitative approaches could also help in this regard.

\section{Broader implications}

According to a growing body of research, procedural justice and police legitimacy perceptions can explain attitudes toward the police across diverse groups, and this seems to be supported by the findings of this exploratory study. Although there are some constraints to the generalizability of these findings, they can serve as a guide to police leaders in their efforts to improve public perceptions of the police, and the involvement of business owners in community safety strategies is recommended. It would be a promising change if police were to see the importance of small businesses in urban neighborhoods. Apart from focusing on homicides and gang related violence, it would help greatly if, in addition, they focused on delinquency and disorder in and around small businesses. This would address some of the perceptions among business owners regarding the ongoing risk of victimization and their concerns about the safety of their customers and family members.

Directed police patrol in high crime areas is another approach to be considered. Studies have found that patrols that include an emphasis on courteous and respectful policing were associated with increased citizen support and reduced violence (Chermak, McGarrell \& Weiss, 2001; McGarrell, Chermak, Weiss \& Wilson, 2001; Sherman \& Rogan, 1995). Police leaders should also be mindful that aggressive policing measures will have a more positive impact on business owners than residential community members. In fact, such policing measures could have a negative effect on residents. Therefore, police can ensure that targeted approaches that keep lines of communication open with community members are used. It can make a difference in public perception if residents are regularly updated by the police themselves on what they aim to accomplish and the ways in which they plan to minimize harmful encounters with citizens (Uchida \& Swatt, 2013).

Understanding the perspectives of first and second generation immigrants in the business community may also be crucial if police are to have any hope of creating partnerships with the owners of high risk business es through-out the city. Given that many of the gas stations in the city are owned and operated by Middle Eastern immigrants, it would serve the public interest if police leaders made a concerted effort to reach out to the gas station owners in their precincts. This could be a step in the 
right direction when it comes to the building of meaningful police-community partnerships with community members who may possess deeply rooted suspicions of the police. Recent efforts by the DPD in partnering with gas station owners to prevent carjacking incidents are an example that such partnerships are possible, and this is a positive sign regarding future efforts to mobilize small business owners (Williams, 2014). These types of initiatives have the potential to influence levels of crime and disorder, but they can also result in more favorable perceptions of police.

\section{References}

Bradford, B., Jackson, J., \& Stanko, E. (2009). Contact and confidence: Revisiting the impact of public encounters with the police. Policing \& Society, 19(1), 20-46.

Braga, A. (2008). Police enforcement strategies to prevent crime in hot spot areas. Technical Report U.S. Department of Justice.

Brantingham, P. (1984). Patterns in crime. Englewood Cliffs, NJ: Prentice Hall College Division.

Brantingham, P., \& Brantingham, P. (1995). Criminality of place: Crime generators and crime attractors. European Journal on Criminal Policy and Research, 3(3), 1-26.

Brodwin, D. (2012). How government can unleash small business to grow the economy. US News $\mathcal{E}$ World Report: Economic Intelligence.

Brunson, R. K. (2007). “Police don't like black people:” African-American young men's accumulated police experiences. Criminology \& Public Policy, 6(1), 71-101.

Cao, L. (2011). Visible minorities and confidence in the police. Canadian Journal of Criminology and Criminal Justice/La Revue canadienne de criminologie et de justice pénale, 53(1), 1-26.

Chermak, S., McGarrell, E. F., \& Weiss, A. (2001). Citizens' perceptions of aggressive traffic enforcement strategies. Justice Quarterly, 18: 2, 365-391.

Dalmia, S. (2013). Why Detroit won't have a second act: Crony capitalism and crushing regulations kill entrepreneurs.

Damron, G. (2013). City of Detroit: We've cleaned up abuses by police, so ease up on federal oversight. Detroit Free Press.

Darden, J. T., Hill, R. C., Thomas, J. M., \& Thomas, R. (1987). Detroit: Race and uneven development. Temple University Press: Philadelphia.

Darden, J. T., \& Thomas, R. W. (2013). Race riots, racial conflicts, and efforts to bridge the racial divide. Michigan State University Press. 
Dudar, H. (2013). Detroit: Closed for business. Al Jazeera America.

Dymski, G. A. (1996). Business strategy and access to capital in inner-city revitalization. The Review of Black Political Economy 24(2), 51-65.

Forbes (2013). The ten most dangerous cities.

Gau, J. M. (2014). Procedural justice and police legitimacy: A test of measurement and structure. American Journal of Criminal Justice 39(2), 187-205.

Gau, J.M. (2011). The convergent and discriminant validity of procedural justice and police legitimacy: An empirical test of core theoretical propositions. Journal of Criminal Justice, 39, 489-498.

Gau, J. M., Corsaro, N., Stewart, E. A., \& Brunson, R. K. (2012). Examining macro-level impacts on procedural justice and police legitimacy. Journal of Criminal Justice, 40(4), 333-343.

Gold, S. J. (2010). The store in the hood: A century of ethnic business and conflict. Rowman and Littlefield.

Greenbaum, R. T., \& Tita, G. E. (2004). The impact of violence surges on neighbourhood business activity. Urban Studies 41(13), 2495-2514.

Gwet, K. L. (2012). Handbook of inter-rater reliability: The definitive guide to measuring the extent of agreement among multiple raters. 3rd ed. Advanced Analytics.

Harris, K. (2013). Detroit: The mecca of black business. Michigan Chronicle.

Jost, J. T., \& Major, B. (2001). The psychology of legitimacy: Emerging perspectives on ideology, justice, and intergroup relations. Cambridge, United Kingdom: Cambridge Univ. Press.

Lepoutre, J., \& Heene, A. (2006). Investigating the impact of firm size on small business social responsibility: A critical review. Journal of Business Ethics, 67(3), 257-273.

Linz, D., Land, K. C., Williams, J. R., Paul, B., \& Ezell, M. E. (2004). An examination of the assumption that adult businesses are associated with crime in surrounding areas: A secondary effects study in Charlotte, North Carolina. Law and Society Review 38(1), 69-104.

McGarrell, E. F., Chermak, S., Weiss, A. \& Wilson, J. (2001). Reducing firearms violence through directed police patrol. Criminology and Public Policy 1(1), 119-148.

Miles, M. B., \& Huberman, A. M. (1994). Qualitative data analysis: An expanded sourcebook. 2nd ed. Thousand Oaks, CA: Sage Publications. 
Nguyen, T. (2005). We are all suspects now: Untold stories from immigrant communities after 9/11. Boston, MA: Beacon Press.

Rice, S.K., \& Parkin, W.S. (2010). New avenues for profiling and bias research: The question of Muslim Americans. In S.K. Rice \& M.D. White (Eds.), Race, ethnicity, and policing: New and essential readings (pp. 450-467). New York, NY: NYU Press.

Sampson, R. J., \& Bartusch, D. J. (1998). Legal cynicism and (subcultural?) tolerance of deviance: The neighborhood context of racial differences. Law and Society Review 32(1), 777-804.

Sampson, R. J., Raudenbush, S. W., \& Earls, F. (1997). Neighborhoods and violent crime: A multilevel study of collective efficacy. Science, 277, 918-924.

Schopmeyer, K. (2011). Arab Detroit after 911: A changing demographic portrait. In N. Abraham, S. Howell and A. Shryock (Eds.), Arab Detroit 9/11 life in the terror decade (pp. 29 61) Detroit, MI: Wayne State University Press.

Sherman, L. W. \& Rogan, D. P. (1995). Deterrent effects of police raids on crack houses: A randomized, controlled experiment. Justice Quarterly 12, 755-781.

Silverman, D. (2010). Doing qualitative research. 3rd ed. London, UK: Sage Publications.

Skogan, W. G. (2006). Asymmetry in the impact of encounters with police. Policing \& Society 16(2) 99126.

Smith, O., Tang, R. Y. W., \& San Miguel, R. (2012). Arab American entrepreneurship in Detroit, Michigan. American Journal of Business 27(1), 58-79.

Spurlock, C. \& Liedka, R. (2013). The near east family: Organized for business? Sociological Perspectives 56(2), 241-260.

Sunshine, J., \& Tyler, T. R. (2003). The role of procedural justice and legitimacy in shaping public support for policing. Law and Society Review, 37(3), 513-548.

Taylor, R. B., \& Lawton, B. A. (2012). An integrated contextual model of confidence in local police. Police Quarterly, 15(14): 414-445.

Tilley, N. (1993). The prevention of crime against small businesses: The safer cities experience. Technical Report-Police Research Group, London Home Office.

Tyler, T. R. (2002). A national survey for monitoring police legitimacy. Justice Research and Policy, 4(1), 71-86. 
Tyler, T. R. (2006a). Psychological perspectives on legitimacy and legitimation. Annual Review of Psychology, 57(1), 375-400.

Tyler, T. R. (2006b). Why people obey the law. Princeton University Press.

Tyler, T. R. (1988). What is procedural justice?: Criteria used by citizens to assess the fairness of legal procedures. Law \& Society Review, 22(1), 103-135.

Tyler, T. R., \& Fagan, J. (2008). Legitimacy and cooperation: Why do people help the police fight crime in their communities? Ohio State Journal of Criminal Law, 6(1), 231-275.

Tyler, T. R., \& Huo, Y. J. (2002). Trust in the law: Encouraging public cooperation with the police and courts. New York, NY: Russell Sage Foundation.

Tyler, T., \& Wakslak, C. (2004). Profiling and police legitimacy: Procedural justice, attributions of motive, and acceptance of police authority. Criminology, 42(2), 253-281.

Uchida, C. D. \& Swatt, M. L. (2013). Operation LASER and the effectiveness of hotspot patrol: A panel analysis. Police Quarterly 16(4), 287-304.

US Census (2010). State and county quick facts. Detroit, Michigan.

Weitzer, R., \& Tuch, S. A. (2005). Racially biased policing: Determinants of citizen perceptions. Social Forces, 83, 1009-1030.

Williams, C. (2014). Detroit Police, gas station owners fight back against carjackings. Detroit Free Press.

\section{Contributors}

Vaughn J. Crichlow is an Assistant Professor in the School of Criminology and Criminal Justice at Florida Atlantic University in Boca Raton. He received his Ph.D. in Criminal Justice from Michigan State University and holds a law degree from the University of London. He also acquired graduate and undergraduate degrees from Rowan University and the University of the West-Indies respectively. His published research examines international and cross-cultural comparisons in communities and crime, policing and private security. His research also focuses on testing theories of crime and deviance.

Edmund F. McGarrell is a Professor in the School of Criminal Justice at Michigan State University. He received his Ph.D. from the State University of New York at Albany (SUNY Albany). His primary research interest is in communities and crime, and the development of evidence-based strategies for violence reduction. He also examines issues in conservation criminology. Since 2002 he has led an MSU team that has served as the national research partner for the U.S. Department of Justice's Project Safe 
Neighborhoods (PSN) program, and he is involved in several projects with criminal justice officials and community partners in Michigan.

\section{Footnotes}

1. This consent decree was an agreement between the Department of Justice (DOJ) and the City of Detroit regarding police policies that needed to be changed. The problems identified by the DOJ were the use of force, in the Detroit Police Department's arrest and detention practices and in the conditions of the holding cells it used to temporarily confine people who are arrested (Damron, 2013). $\doteq$

2. Pseudonyms are used in place of the participants' names. $\bullet$ 